\title{
Microscopia confocal secuencial de regeneración nerviosa corneal en operado de miopía por PRK
}

\section{Sequential confocal microscopy of corneal nerve regeneration in myopia surgery by PRK}

\author{
Eduardo Rojas-Alvarez ${ }^{1 *}$ y Janet González-Sotero² \\ ${ }^{1}$ Universidad de Cuenca, Cuenca; ${ }^{2}$ Universidad Católica de Santiago de Guayaquil, Guayaquil. Ecuador
}

Se observan diferentes momentos de regeneración del nervio estromal y del plexo nervioso subbasal, en imágenes tomadas en la misma profundidad con microscopio Confoscan 4® (NIDEK). Los nervios estromales se ubican en el estroma anterior y medio, aparecen como estructuras lineales, delgadas, reflectivas, en varias orientaciones, con patrón dicotómico, no se observan detalles internos de los nervios ${ }^{1}$. En la secuencia se observa el aumento de la reflectividad y longitud del nervio durante el primer año de postoperatorio. Los nervios subbasales están localizados entre la membrana de Bowman y el epitelio basal. Aparecen como estructuras lineales con reflectividad homogénea, aspecto dicotómico en forma de $\mathrm{Y}$, y fibras de interconexión finas en forma de $\mathrm{H}^{1}$. La ausencia de corte lamelar influye en que, posterior a PRK, se recuperen de forma más rápida las características preoperatorias del plexo nervioso subbasal, y esta recuperación es total al año de la operación. La profundidad de la ablación, la cantidad de tejido removido en el estroma y la profundidad de daño a los nervios estromales se encuentran estrechamente relacionados ${ }^{2}$ figura 1.

\section{Responsabilidades éticas}

Protección de personas y animales. Los autores declaran que para esta investigación no se han realizado experimentos en seres humanos ni en animales.

Confidencialidad de los datos. Los autores declaran que han seguido los protocolos de su centro de trabajo sobre la publicación de datos de pacientes.

Derecho a la privacidad y consentimiento informado. Los autores han obtenido el consentimiento informado de los pacientes y/o sujetos referidos en el artículo. Este documento obra en poder del autor de correspondencia.

\section{Financiamiento}

Los autores no recibieron patrocinio para llevar a cabo este artículo.

\section{Conflicto de intereses}

Los autores declaran no tener ningún conflicto de intereses.

\section{Bibliografía}

1. Rojas Álvarez E, González Sotero J, Tamargo Barbeito TO. Mode-los predictivos de morfometría corneal a partir de la ametropía atratar con láser excímer. Arch Soc Esp Oftalmol. 2015;90:312-23.

2. Rojas Álvarez E, González Sotero J. LASIK vs. LASEK desde laperspectiva morfométrica corneal in vivo. Rev Mex Oftalmol.2013;87:145-57. 


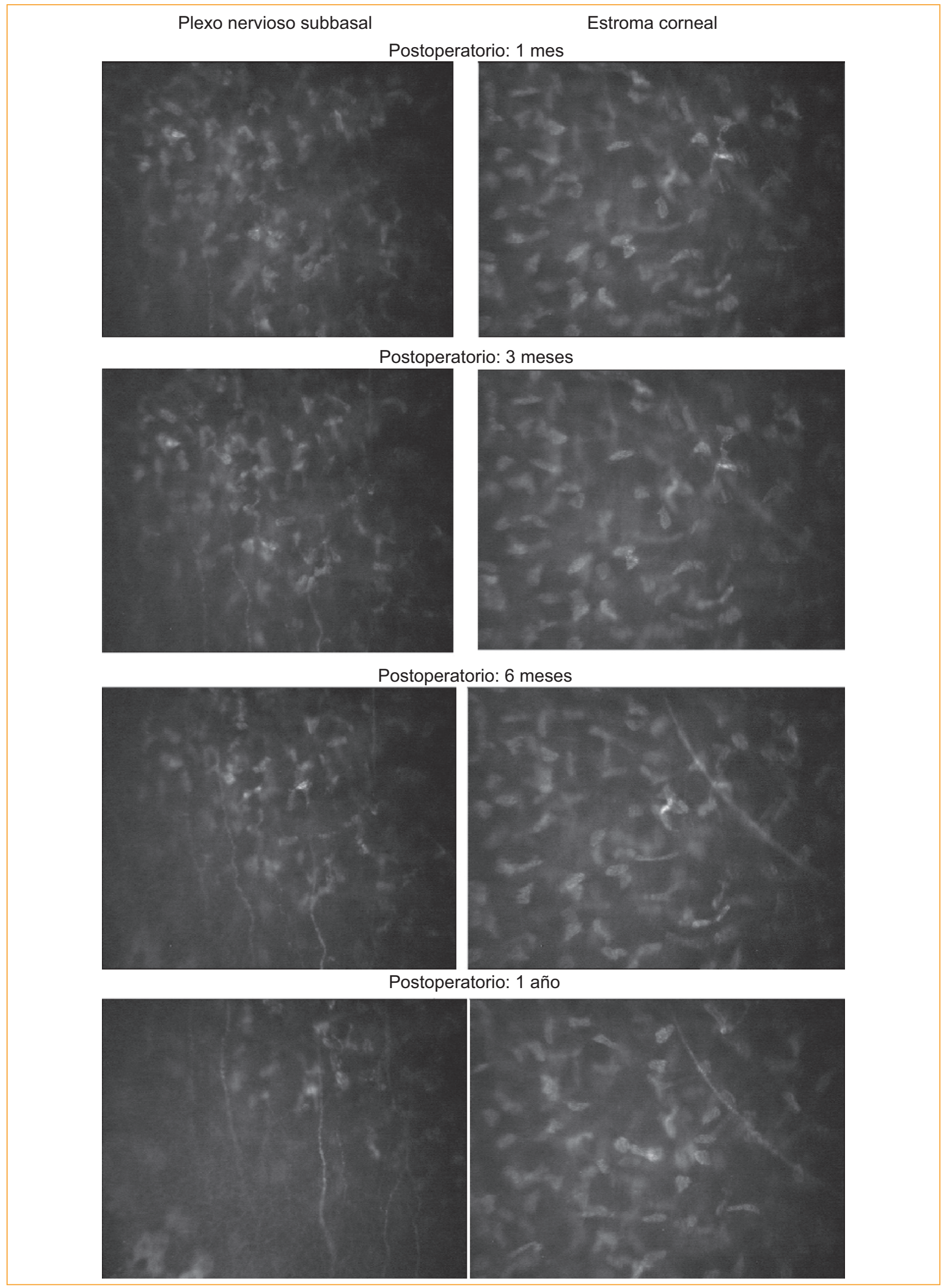

Figura 1. Imágenes secuenciales de microscopía confocal. Paciente operado de miopía por PRK, en diferentes momentos postoperatorios: 1 mes, 3 meses, 6 meses, 1 año. A la derecha estroma corneal a la izquierda plexo nervioso subbasal. 